\title{
Do the school adaptation levels of preschoolers vary according to their relationship with their teachers?
}

\author{
Filiz Erbay $^{1}$, Neslihan Durmuşoğlu Saltalı ${ }^{2}$ \\ ${ }^{1}$ Preschool Education Department, Near East University, Turkey \\ ${ }^{2}$ Preschool Education Department, Ordu University, Turkey
}

\section{Article Info \\ Article history: \\ Received Feb 15, 2020 \\ Revised Sep 27, 2020 \\ Accepted Oct 17, 2020}

\section{Keywords:}

Preschool education School adaptation Teacher-child relationship

\begin{abstract}
In this study, the differentiation status of preschool children's adaptation to school according to their relationship with teachers was examined. The study participants consisted of 326 children aged 60-72 months and 21 preschool teachers in different preschool educational institutions affiliated to the Provincial Directorate of National Education in Konya, Turkey. The School Adaptation Teacher Assessment Scale and Teacher-Student Relationship Scale were utilized to collect the research data. In the evaluation of the research data, firstly, teacher-child relationship scores were divided into groups for cluster analysis: conflictual/non-conflictual, dependent/ independent, and close/distant teacher-child relationship. The data gathered were analyzed using the independent-samples t-test. The results of the study revealed that the level of school adaptation of the children who had close, non-conflictual, and independent relationships with their teachers differed significantly from that of children who had distant, conflictual, and dependent relationships with their teachers. Positive teacher-child relationships reflected positively on the level of the child's school adaptation level. Teachers should establish close relationships with children in order to facilitate their adaptation to the school in the preschool period.
\end{abstract}

This is an open access article under the CC BY-SA license.

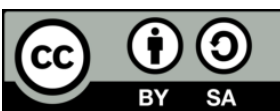

Corresponding Author:

Neslihan Durmuşoğlu Saltalı,

Preschool Education Department,

Faculty of Education,

Ordu University,

Ordu, Turkey.

Email: ndsaltali@gmail.com

\section{INTRODUCTION}

Throughout their childhood, children experience different environmental transitions that require adaptation to new environments. This environmental transition can sometimes be due to a change of home, city, start of school, or school. In the environmental transition processes, the child has to adapt to the new environment by struggling with many difficulties. Schooling is also an environmental transition that requires the child's adaptation to the school environment as a whole, as he/she leaves the home environment where he/she was born and raised, when his/her first school life begins [1].

In general, school adaptation requires that a child adapts to many variables, such as teachers, classroom settings, school and classroom rules, and peer relationships [2-4]. If the child is not supported by these factors within the school and adequate school readiness is not achieved, the child's healthy adaptation to school cannot be ensured [5,6]. School adaptation is an important process that plays a vital role in a child's life [7]. Whether this process is positive or negative, it has an impact on many factors, such as child 
development, success, anxiety level, loneliness level, social support perception, and academic [3, 8, 9]. According to scientific literature, children who adapt to schooling in the preschool period pay much attention in class, participate actively in activities, work independently, achieve higher academic success, and improve peer relations $[10,11]$. In addition, other evidence suggests that children who cannot adapt to school suffer from various difficulties in their classrooms [11, 12]. They face difficulties adapting to school in later educational levels; they may have internal/external psychological problems; they achieve low academic success [1, 13-15]. All these results reveal the importance of investigating the adaptation of the child to school in the preschool period.

Regardless of the extent of the child's preparation on adaptation to school, he/she may still falter and have difficulties adapting during the first days of school. Right from the first day of school, the pupil of his/her family is separated from his/her parents when he/she is included in the school environment, and he/she is expected to relate well with people he/she does not know for most of the day. In this process, the child's relationship with the teacher is particularly important, with respect to being under an adult authority for the first time after his/her parents $[2,16]$. Bronfenbrenner emphasizes that this transition between home and school and the adaptation to school, plays an important role in the development of the child in the ecological systems model [17]. The ecological model argues that children's transition to school should be successfully shaped by the support provided by the family at home, and by the teacher at school [18, 19]. In this process, it is thought that the relationship established between the teacher and child influences school adaptation. In the process of adaptation to school, the child should be made to feel comfortable in the classroom, loved, and made to love himself/herself. The teacher should also have empathic communication with the child and be patient and tolerant $[2,18,20,21]$.

Birch and Ladd emphasize the importance of considering the various characteristics of children's relationships with classroom teachers when examining school adaptation of young children [11]. The classroom environment creates a natural environment to reflect the relationships children have with their parents. The support provided by the teachers in the relationship can be used to nurture the child's development and mitigate the risk factors involved [22]. Studies based on an extended attachment perspective evaluate the emotional quality of a teacher's relationship with a particular student, in terms of three dimensions initially derived from concepts and measures in the parent-child attachment theory: closeness, conflict, and dependence. Closeness refers to the relationship between the teacher and child based on love, trust, warmth, and openness. Conflict reflects incompatible and coercive interactions between the teacher and child. Dependence refers to the child's extremely dependent and adhering behavior to the teacher. In this perspective, closeness is considered to be positive, whereas conflict and dependence are considered as the most prominent features of a negative teacher-child relationship [23-26]. The purpose of this study is to determine whether the level of school adaptation differs according to these forms of relationship established by the preschool child with their teachers.

When the literature was examined, teacher-student relationships with different variables executive function [27]; social anxiety [28]; aggression [29]; internalization/externalization behaviors [30]; school type [31]; academic results [32,33] and studies on children's adaptation to school levels peer relations [34]; peer acceptance [35]; mother attitude-social skills [36]; and general adaptation level [37] were identified. However, only a few studies focused on school adaptation and teacher-student relationships [38, 39]. These studies emphasized the importance of teacher-child relationships and the process of the child's adaptation to school and drew attention to the need to investigate these relationships [13]. The regions in this study differ, in terms of being culturally different from the regions where the current studies were conducted (Adana and Samsun). In addition, the current studies also included suggestions to address teacher-child relationships and school adaptation in new studies with different measurement tools, samples, and methods [38, 39]. This study was developed based on these suggestions; teacher-student relationship data were grouped using the clustering method; the students' adaptation to school was investigated to be either different or not with different teacher-student relationship types. The study also differs from the literature in this respect. The general aim of the study is to reveal whether the school adaptation levels of preschoolers differ according to the teacher-child relationship.

\section{RESEARCH METHOD}

This research was conducted using a descriptive survey model. The purpose of the survey model was to describe a past or ongoing situation as it exists [40]. This study sought to answer the question of whether the adaptation of preschool children to school differs according to the teacher-student relationship. 


\subsection{Sample}

To determine the study sample in the 2018-2019 academic year, 21 schools were selected by the random cluster sampling method from 126 schools in the central districts of Konya, including independent kindergartens and primary schools including preschool classroom within the Ministry of National Education. Afterwards, all teachers and students of a classroom were randomly selected for inclusion in this study by drawing lots from these schools. Therefore, the study participants consisted of 326 children in the 60-72 months age group and 21 preschool teachers in preschool educational institutions (21 different schools) affiliated to the Provincial Directorate of National Education in Konya. All of the teachers participating in the research were female; for the preschoolers, 171 were boys and 155 were girls. The mean age of the teachers was 36.72 years; that of the children was 62.3 months.

\subsection{Data collection method}

Personal information form, teacher-child relationship scale, and school adaptation teacher assessment scale for 60-72 months old children were used to collect data.

\subsubsection{Personal information form} was obtained.

With the personal information form, information about the age and gender of teachers and children

\subsubsection{School adaptation teacher assessment scale}

Ladd, Kochenfender, and Coleman developed the scale to determine the level of school adaptation of children 60-72 months old [41]; Önder and Gülay later adapted the scale into Turkish. The scale consists of 25 items and four sub-dimensions. The sub-dimensions included in the scale were school liking, cooperative participation, school avoidance, and self-management. The 'school liking' subscale consists of five items and measures teachers' opinions about how much the child likes school. The 'cooperative participation' subscale consists of eight items and measures the teacher's authority, class rules, and responsibilities. The 'school avoidance' subscale consists of five items; it reflects the tendency for the child to avoid the classroom. Seven items are found in the 'self-management' subscale, and the scale measures the independent and self-centered behaviors of the child in the classroom. Each item in the scale was evaluated with the expressions, "Not Appropriate", "Appropriate", and "Completely Appropriate" [42]. In this study, Cronbach's alpha internal consistency coefficients of the measurement tool were analyzed. From the analysis, internal consistency coefficients were 0.72 for the whole scale and $0.84,0.82,0.72$, and 0.73 for the school liking, cooperative participation, school avoidance, and self-management subscales, respectively. Cronbach's alpha values showed that the measurement tool was reliable.

\subsubsection{Teacher-student relationship scale}

The teacher-student relationship scale is a 28-item 5-point Likert-type scale designed to assess teacher-student relationships. It is a self-assessment tool in which the teacher assesses his/her relationship with each student [23]. The scale was designed to evaluate the relationship between children aged 4-8 years and their teachers. Its adaptation into Turkish was performed by Şahin [43]. The scale has three subdimensions. The first sub-dimension is the 12-item conflict sub-dimension, which was used to reveal the negative interactions and conflict in the relationship between the student and teacher. The second subdimension was the proximity sub-dimension, consisting of 11 items that assessed the close and positive relationship between the student and teacher. The third sub-dimension was the addiction sub-dimension consisting of five items for evaluating the dependency-based relationship between the teacher and student (how much the teacher sees the student as dependent on himself/herself). Cronbach's alpha internal consistency coefficients of this measurement tool were analyzed. From the analysis, the consistency coefficients were .79 for the whole scale and $0.83, .86$, and .71 for the conflict, proximity, and dependence sub-dimensions, respectively. Cronbach's alpha values indicated that the measurement tool was reliable [43].

\subsection{Statistical analysis}

Kolmogorov Smirnov test was used to determine whether the variables were normally distributed before further statistical analyses of the research data. In the statistical analysis, the teacher-child relationship scores were first divided into groups by means of clustering analysis, and then the t-test was implemented to determine whether any difference existed among the groups. Clustering analysis is a method that allows classifying units examined in a study according to their similarities in groups, to reveal the common properties of the units, and to make general definitions about these classes [44]. According to the teacherchild relationship scores after the clustering analysis, the relationships between the groups and the teacher 
were either conflictual/non-conflictual, dependent/independent, and close/distant. Statistical Package for the Social Sciences (SPSS from IBM) 23.0 statistical package program was utilized to evaluate the research data.

\section{RESULTS}

3.1. Results of the analysis of school adaptation levels of 60-72 months old children who have conflictual/non-conflictual relationship with their teachers

The results of the statistical analysis of the school adaptation levels of 60-72 months old children who are in a conflictual/non-conflictual relationship with their teachers, the first sub-problem of the study, are presented in Table 1.

Table 1. Preschooler school adaptation levels with conflictual/non-conflictual teacher-child relationship

\begin{tabular}{cccccc} 
& \multicolumn{2}{c}{ Non-Conflict $(\mathrm{n}=238)$} & \multicolumn{2}{c}{ Conflict $(\mathrm{n}=88)$} & \multirow{2}{*}{ t-values } \\
& $\mathrm{X}$ & $\mathrm{Sd}$ & $\mathrm{X}$ & $\mathrm{Sd}$ & \\
\hline Cooperative participation & 14.47 & 2.21 & 11.84 & 4.98 & $10.22 * * *$ \\
School avoidance & 0.58 & 0.38 & 3.06 & 2.37 & $-9.54 * * *$ \\
Self-management & 8.78 & 1.50 & 5.31 & 2.27 & $13.23 * * *$ \\
School liking & 8.69 & 0.84 & 6.06 & 1.66 & $14.15^{* * *}$ \\
General school adaptation & 31.36 & 3.52 & 20.15 & 5.90 & $21.21 * * *$ \\
\hline
\end{tabular}

$$
\text { *** } \mathrm{p}<0.001
$$

When Table 1 is examined, it is observed that 238 of the preschool children who participated in the study had no conflict with their teachers, whereas 88 of them had conflicts with their teachers. When the students who had non-conflictual relationships with their teachers were compared with those who had conflictual relationships, the levels of participation, self-management, school liking, and total school adaptation were determined to be statistically significantly higher $(\mathrm{p}<0.001)$. Among the negative indicators of school adaptation, the level of school avoidance was determined to be statistically significantly lower in non-conflictual relationships with teachers $(\mathrm{p}<0.001)$.

\subsection{Results of the analysis of the school adaptation levels of 60-72 months old children who are in} dependent/independent relationships with their teachers

The statistically adjusted results of the analysis, assessing the difference between both groups of the second sub-problem considered in this study, dependent/independent relationships between 60-72 months school children and their teachers, are presented in Table 2.

Table 2. Preschooler school adaptation levels according to dependent/independent teacher-child relationship

\begin{tabular}{cccccc}
\hline & \multicolumn{2}{c}{ Independence $(\mathrm{n}=226)$} & \multicolumn{2}{c}{ Dependence $(\mathrm{n}=100)$} & \multirow{2}{*}{$\mathrm{t}$-values } \\
& $\mathrm{X}$ & $\mathrm{Sd}$ & $\mathrm{X}$ & $\mathrm{Sd}$ & \\
\hline Cooperative participation & 14.70 & 1.92 & 10.98 & 4.77 & $11.59 * * *$ \\
School avoidance & 0.56 & 0.37 & 2.82 & 2.36 & $-9.23 * * *$ \\
Self-management & 8.92 & 1.38 & 5.42 & 2.20 & $14.67 * * *$ \\
School liking & 9.79 & 0.59 & 7.16 & 1.70 & $15.01 * * *$ \\
General school adaptation & 32.85 & 2.84 & 10.74 & 5.78 & $23.23 * * *$ \\
\hline$* * * \mathrm{p}<0.001$ & & & & &
\end{tabular}

When Table 2 is examined, it is observed that 226 of the preschool children participating in the study are independent of their teachers, whereas 100 of them are dependent. When the students who were independent of their teachers were compared with those who were dependent, the levels of cooperative participation, self-management, school liking, and total school adaptation were determined to be statistically significantly higher $(\mathrm{p}<0.001)$. Conversely, avoidance of school, which is one of the negative indicators of school adaptation, was found to be significantly lower in children who had independent relationships with their teachers $(\mathrm{p}<0.001)$. 


\subsection{Results of the analysis of the school adaptation levels 60-72 months old children who have close/distant relationship with their teachers}

The results of the statistical analysis of the school adaptation levels of 60-72 months old children who were in a close/distant relationship with their teachers are presented in Table 3. Table 3 revealed that 230 of the preschool children participating in the research were close to their teachers, whereas 96 of them were distant. When the students who were close to their teachers were compared with those who were distant, the levels of participation, self-management, school commitment, and total school adaptation were found to be statistically significantly higher $(\mathrm{p}<0.001)$. Conversely, the level of school avoidance, which is one of the negative indicators of school adaptation, was found to be significantly lower in children who had close relationships with their teachers $(\mathrm{p}<0.001)$.

Table 3. Preschooler school adaptation levels according to close/distant teacher-child relationship

\begin{tabular}{cccccc}
\hline & \multicolumn{2}{c}{ Closeness $(\mathrm{n}=230)$} & \multicolumn{2}{c}{ Distance $(\mathrm{n}=96)$} & \multirow{2}{*}{ t-values } \\
& $\mathrm{X}$ & $\mathrm{Sd}$ & $\mathrm{X}$ & $\mathrm{Sd}$ & \\
\hline Cooperative participation & 14.66 & 1.98 & 9.85 & 4.78 & $11.48^{* * *}$ \\
School avoidance & 0.57 & 0.36 & 2.87 & 2.39 & $-9.09^{* * *}$ \\
Self-management & 8.83 & 1.51 & 5.47 & 2.21 & $13.55^{* * *}$ \\
School liking & 9.73 & 0.78 & 7.18 & 1.68 & $14.19^{* * *}$ \\
General school adaptation & 32.65 & 3.12 & 19.63 & 5.99 & $21.70^{* * *}$ \\
\hline$* * * \mathrm{p}<0.001$ & & & &
\end{tabular}

\section{DISCUSSION}

In this study, the differentiation status of preschool children's adaptation to school according to their relationship with teachers was examined. The results of the study revealed that the children who had nonconflictual relationships with their teachers had higher levels of cooperative participation, self-management, school liking, and general school adaptation than children who had conflictual relationships. These results indicate that the non-conflictual relationship between a child and teacher facilitates the child's adaptation to school. When the literature was examined, the findings of other studies were consistent with those of our study. Murray, et al. emphasize that positive relationship, such as the conflict-free relationship between teachers and young children, can help facilitate school transition and promote positive social emotional health and development among young children [45]. Göktaş and Gülay-Ogelman stated that a meaningful relationship existed between preschool children's adaptation to school and a conciliatory teacher-student relationship [38].

Roorda, et al. evaluated the relationship between teachers and students through meta-analysis and stated that positive teacher-student relations based on proximity contributed to children's social emotional adjustment [24]. Pianta and Stulhman also stated that a relationship exists between teacher-child relationship and children's social skills and academic achievement [14]. In the literature, social skills are also evaluated as skills that facilitate the child's adaptation to school, which are consistent with our research results [38]. The study also found that children who had non-conflictual relationships with their teachers had lower levels of school evasion, which is a negative indicator of school adaptation, than children with conflictual relationships. Similar to this study, Nur, et al. found a positive and significant relationship between conflictual teacher-child relationships and school-avoiding behaviors. The results of the first sub-problem of the study indicated that the existence/absence of a conflictual relationship between the teacher and student is an important variable in the child's adaptation to school [39].

The second finding of the study is that in a relationship where the child is independent of the teacher, the child's adaptation to school is positively affected. The level of school avoidance was found to be higher in children who were dependent on their teachers than in those who were independent. Lower levels of cooperative participation, self-management, liking, and general school adaptation were also observed among dependent children. Different studies provide findings that are consistent with those of our study. Göktaş and Gülay-Ogelman found that a negative and significant relationship existed between the level of a child's dependence on his/her teacher and the child's school adaptation [38]. Glüer and Gregoriadis in their study in Germany, found a negative relationship between school-based dependence and school adaptation, and a positive relationship between behavioral problems and school adaptation. These results are consistent with the findings of this study [46].

The third finding of the study is related to the extent of the closeness of the child to the teacher. It has been shown that the levels of cooperative participation, self-management, school liking, and general school adaptation of children who are close to their pre-school teachers are higher than those of children who are distant from their teachers. Similarly, the level of school avoidance of children who were close to their teachers was lower than those who were distant. In the literature, Göktaş and Gülay-Ogelman and Nur, et al.

Do the school adaptation levels of preschoolers vary according to their relationship with ... (Filiz Erbay) 
also showed that a significant relationship exists between a close teacher-student relationship and preschool children's adaptation to school $[38,39]$. Baker, in a large sample study on primary school children, stated that the close teacher-child relationship reduces children's behavioral and adaptation problems that affect school adaptation, and eases school adaptation [47]. These findings corroborate our research findings. Hargreaves stated that teachers who are effective and close in relationship, with emotional sharing, with their students, provide gains in social and emotional fields, especially for preschool children [48]. They also claimed that "emotions are at the center of teaching" and "good teaching is loaded with positive emotions" [49]. Teachers who place emotions at the center of teaching are generally more sensitive to the emotional needs of students and establish a closer relationship with them. In this close relationship that children have with their teachers, establishing an adult and warm attachment pattern, after primary caregivers, may be the reason for their high school adaptation scores. Taken together, this study indicates that preschool children will have higher adaptation with their teachers if they have close, non-conflictual, and independent relations with their teachers.

\section{CONCLUSION}

Taken together, this study indicated that preschool children will have higher adaptation with their teachers if they have close, non-conflictual, and independent relations with their teachers. The results of this study are important for drawing attention to the teacher-student relationship, in ensuring the child's adaptation to school by showing that the relationship between the child's school adaptation and the teacher in the preschool period varies according to the close/distant, conflictual/non-conflictual, and dependent/independent nature of the relationship. However, the study has some limitations. First, the study was conducted with 21 teachers and 326 children aged 60-72 months in Konya. In future studies, the adaptation of younger children to school can be considered to investigate whether it changes according to the student-teacher relationship. Longitudinal studies may also be used to further clarify the effect of the studentteacher relationship on children's adaptation to school. In addition, the research can be repeated in different parts of the country to provide information about the sensitivity of the results to cultural changes.

Second, the data used in the research were obtained from the teachers. In future research, studies on the teacher-child relationship can be planned based on child evaluation. Similarly, studies in which school adaptation is handled through methods, such as observation and interview, can be conducted. To improve school adaptation studies, the effect of the relationship between preschool children and other individuals, such as their parents, siblings, caregivers, and peers with whom they have a primary relationship, should be considered by the researchers. Additionally, teachers should be informed of the results of these and similar studies; they should also be informed about the importance of teachers in school adaptation. In-service training should include theoretical knowledge and practices to support teachers in establishing close relationships with children. In preschool education undergraduate programs, information, and practices that develop teacher-child relationship should be discussed in detail.

Despite the limitations of the study, the results and recommendations of the study may contribute to parents, educators, child development specialists, administrators, child psychologists and psychiatrists, and academics. This expected contribution will be to raise awareness that the relationship between the child and the teacher affects the child's school adaptation in the preschool period.

\section{REFERENCES}

[1] Seven, S., "Development of School Adaptation Teacher Evaluation Scale," Turkish Educational Sciences Journal, vol. 9, no. 1, pp. 29-42, 2011.

[2] Erten, H., "Okul öncesi eğitime devam eden 5-6 yaş çocuklarının sosyal beceri, akran ilişkileri ve okula uyum düzeyleri arasındaki ilişkilerin izlenmesi," Master thesis, Denizli, Pamukkale University, 2012.

[3] Lakhani, P. K., Jain, K. and Chandel, P. K., "School adjustment, motivation and academic achievement among students," International Journal of Research in Social Sciences, vol. 7, no. 10, pp. 333-348, 2017.

[4] Besi, M. and Sakellariou, M., "Children's dificulties in transition to primary school in Greece," European Journal of Social Sciences Studies, vol. 4, no. 1, pp. 142-153, 2019.

[5] Berger, R. H., Valiente, C., Eisenberg, N., Hernandez, M. M., Thompson, M., Spinrad, T., VanSchyndel, S., Silva, K. and Southworth, J., "Effortful control and school adjustment: The moderating role of classroom chaos," J Appl Dev Psychol, vol. 53, pp. 108-119, Nov. 2017.

[6] Durmuşoğlu Saltali, N. and Erbay, F., "Stressful situations experienced by six-year-old children when starting preschool education," Educational Research and Reviews, vol. 8, no. 9, pp. 519-524, 2013.

[7] Besi, M. and Sakellariou, M., "Transition to primary school the importance of social skills," International Journal of Humanities and Social Science (SSRG-IJHSS), vol. 6, no. 1, pp. 33-36, 2019. 
[8] Aygün, H. E., "Birinci sınıf öğrencilerinin okula uyumları ve okuma-yazma becerilerinin kazanımı," Akdeniz Ĕ̈itim Araştırmaları Dergisi, vol. 13, no. 27, pp. 521-537, 2019.

[9] Magnuson, K., Duncan, G. J., Lee, K. T. H. and Metzger, M. W., "Early school adjustment and educational attainment," American Educational Research Journal, vol. 53, no. 4, pp. 1198-1228, 2016.

[10] Uysal, H., Aydos, E. H. and Akman, B., "Okul öncesi dönem çocuklarının sınıfa uyumlarının çeşitli değişkenler açısından incelenmesi," GEFAD, vol. 36, no. 3, pp. 617-645, 2016.

[11] Birch, S. H., and Ladd, G., "The teacher-child relationship and children's early school adjustment," Journal of School Psychology, vol. 35, no. 1, pp. 61-79, 1997.

[12] Başaran, S., Gökmen, B. and Akdağ, B., "Okul öncesi eğitimde okula uyum sürecinde öğretmenlerin karşıllaştığ1 sorunlar ve çözüm önerileri," Uluslararası Türk eğitim Bilimleri Dergisi, vol. 2014, no. 2, pp. 197-223, 2014.

[13] Jerome, E. M., et al., "Teacher-child relationships from kindergarten to sixth grade: early childhood predictors of teacher-perceived conflict and closeness," Social Development, vol. 18, no. 4, pp. 915-945, 2009.

[14] Pianta, R. C., and Stuhlman, M. W., "Teacher-child relationships and children's success in the first years of school," School Psychology Review, vol. 33, no. 3, pp. 444-458, 2004.

[15] Kim, S. J., Kwon1, S. M. and Han, W., "Development of a school adaptation program for elementary school students with hearing impairment," Journal of Audiology \& Otology, vol. 19, no. 1, pp. 26-33, 2015.

[16] Öz, A. Ş. and Dolapçığlu, S., "Evaluating the student-teacher relationship in elementary schools: My Teacher \& IChild," Asian Journal of Education and Training, vol. 5, no. 1, pp. 8-17, 2019.

[17] Bronfenbrenner, U., "Ecological models of human development," In T. Husen and T. N. Postlethwaite (Eds.), International Encyclopedia of Education (2nd ed.), Oxford, UK: Pergamon/Elsevier Science, 1994.

[18] Bağçeli Karaman, P., Şen, T., Alataş, S. and Tütüncü, B., "Okul öncesi dönemde okula uyum sürecine ilişkin öğretmen görüşleri,” Abant İzzet Baysal Üniversitesi Eğitim Fakültesi Dergisi, vol. 18, no. 2, pp. 681-701, 2018.

[19] Demirtaş-Zorbaz, Z., Özeri A., Gençtanırım-Kurt, D. and Ergene, T., "Öğretmen - öğrenci ilişki ölçeği’nin (ööiö) uyarlanması: adaptation of teacher - student relationship scale (Strs)," Journal of Measurement and Evaluation in Education and Psychology, vol. 7, no. 2, pp. 407-418, 2016.

[20] Varga, M., "The effect of teacher-student relationships on the academic engagement of students," Master thesis, Goucher College, Baltimore, USA, 2017.

[21] Öztürk-Samur, A. and İnal-Kızıltepe, G., “Okulum ve öğretmenim hakkında ne düşünüyorum?” Hitit University Journal of Social Sciences Institute, vol. 10, no. 2, pp. 1257-1276, 2017.

[22] Ası, D. Ş. and Karabay, Ş.O., "Öğrenci-öğretmen ilişki ölçeği-kısa formunun Türkçe’ye uyarlanması,” Ege Eğitim Dergisi, vol. 19, no. 1, pp. 67-82, 2018

[23] Pianta, R.C. Students, teachers, and relationship support: Professional manual. U.S.A: Psychological Assessment Resources, Inc, 2001.

[24] Roorda, D. L., et al., "The influence of affective teacher-student relationships on students' school engagement and achievement: a meta-analytic approach," Review of Educational Research, vol. 81, no. 4, pp. 493-529, 2011.

[25] Choi, J. Y. and Dobbs-Oates, J., "Teacher-child relationships: contribution of teacher and child characteristics," Journal of Research in Childhood Education, vol. 30, no. 1, pp. 15-28, 2016.

[26] Hershkovitz, A., "The student-teacher relationship in the one-to-one computing classroom," Revista Páginas de Educación. vol. 11, no. 1, pp. 37-65, 2018.

[27] McKinnon, R. D. and Blair, C., "Does early executive function predict teacher-child relationships from kindergarten to second grade?" Developmental Psychology, vol. 54, no. 11, pp. 2053-2066, 2018.

[28] Durmuşoğlu-Saltal1, N. "The teacher student relationship as a predictor of preschoolers' social anxiety," Mevlana International Journal of Education, vol. 3, no. 4, pp. 118-126, 2013.

[29] Lee, P. and Bierman, K. L., "Longitudinal trends and year-to-year fluctuations in student-teacher conflict and closeness: associations with aggressive behavior problems," School Psychology, vol. 70, pp. 1-15, Oct. 2018.

[30] Baker, J. A., Grant, S., and Morlock, L., "The teacher-student relationship as a developmental context for children with internalizing or externalizing behavior problems," School Psychology Quarterly, vol. 23, no. 1, pp. 3-15, 2008.

[31] Skalická, V., et al., "Preschool-age problem behavior and teacher-child conflict in school: direct and moderation effects by preschool organization," Child Development, vol. 86, no. 3, pp. 955-964, 2015.

[32] Hughes, N., "Longitudinal effects of teacher and student perceptions of teacher-student relationship qualities on academic adjustment," The Elementary School Journal, vol. 112, no. 1, pp. 38-60, 2011.

[33] Barille, J.P., et al., "Teacher-student relationship climate and school outcomes: implications for educational policy initiatives," J. Youth Adolescence, vol. 41, no. 3, pp. 256-267, 2012.

[34] Gülay, H., "5-6 yaş grubu çocuklarda okula uyum ve akran ilişkileri," Electronic Journal of Social Sciences, vol. 10, no. 36, pp. 1-10, 2011.

[35] Gülay, H. and Erten, H. "Okul öncesi dönem çocuklarının akran kabullerinin okula uyum değişkenleri üzerindeki yordayı1 etkisi," e-International Educational Research Journal, vol. 2, no. 1, pp. 81-92, 2011.

[36] Gülay Ogelman, H., et al., "Anne Tutumlarının 5-6 yaş çocuklarının sosyal becerilerini ve okula uyumlarını yordayıcı etkisi," Selçuk Üniversitesi Sosyal Bilimler Enstitüsü Dergisi, no. 29, pp. 143-152, 2013.

[37] Erbay, F., "An examination of adaptation levels of children in terms of the variable of teacher- child communication," Early Child Development and Care, 2019. [Online]. Available: https://www.tandfonline.com/doi/full/10.1080/03004430.2019.1683006

[38] Göktaş, İ. and Gülay-Ogelman, H., "Okul öncesi eğitimde öğretmen-öğrenci ilişkisinin öğrencilerin okula uyum düzeyleri üzerindeki yordayıcı etkisinin incelenmesi," International Anatolia Academic Online Journal, vol. 5, no. 1, pp. 30-42, 2019. 
[39] Nur, İ., Aktaş-Arnas, Y., Abbak, B. S., and Kale, M., "Mother-child and teacher child relationships and their associations with school adjustment in pre-school," Kuram ve Uygulamada Eğitim Bilimleri, vol. 18, no. 1, pp. 201-220, 2018.

[40] Karasar, N., Bilimsel Araştırma Yöntemleri, 35 Baskı. Ankara: Nobel Yayıncılık, 2020.

[41] Ladd, G. W., Kochenfender, B. J., and Coleman, C. C., "Friendship quality as a predictor of young children's early school adjustment," Child Development, vol. 67, no. 3, pp. 1103-1118, 1996.

[42] Önder, A. and Gülay, H., "5-6 yaş çocukları için Okula Uyum Öğretmen Değerlendirme Ölçeği' nin güvenirlik ve geçerlik çalışması," International Online Journal of Educational Sciences, vol. 2, no. 1, pp. 204-224, 2010.

[43] Şahin, D., "Öğrenci-Öğretmen İlişki Ölçeği'nin Türkçeye uyarlanması," Eğitim Bilimleri ve Uygulama, vol. 13, no. 25, pp. 87-102, 2014.

[44] Kaufman, L. and Rousseeuw, P. J., Finding groups in data: An introduction to cluster analysis. New York: John Wiley and Sons, 1990.

[45] Murray, C., Murray, K. M. and Waas, G. A., "Child and teacher reports of teacher-student relationships: Concordance of perspectives and associations with school adjustment in urban kindergarten classrooms," Journal of Applied Developmental Psychology, vol. 29, no. 1, pp. 49-61, 2008.

[46] Glüer, M. and Gregoriadis, A., "Quality of teacher-child relationship and preschoolers' prosocial behaviour in German kindergartens," Education 3-13, vol. 45, no. 5, pp. 558-571, 2017.

[47] Baker, J. A., "Contributions of teacher-child relationships to positive school adjustment during elementary school," Journal of School Psychology, vol. 44, no. 3, pp. 211-229, 2006.

[48] Hargreaves, A., "The emotional practice of teaching," Teaching and Teacher Education, vol. 14, no. 8, pp. 835-854, 1998.

[49] Yan, E. M., Evans, I. A., and Harvey, S. T., "Observing emotional interactions between teachers and students in elementary school classroom,” Journal of Research in Childhood Education, vol. 25, no. 1, pp. 82-97, 2011. 